\title{
Narrating Otherness in Poland and Sweden - European Heritage as a Discourse of Inclusion and Exclusion
}

Krzysztof Kowalski, Łucja Piekarska-Duraj \& Barbara Törnquist-Plewa (red.). Berlin: Peter Lang, 2019

320 sider. ISBN 9783631784129

Anmeldt av Jørn Holm-Hansen [dr. polit., seniorforsker ved By- og regionforskningsinstituttet NIBR - OsloMet, jornhh@oslomet.no]

Som det framgår av redaktørenes innledende kapittel, tar denne antologien sikte på å analysere «annethet» basert på kultur, etnisitet, klasse og kjønn i den offentlige diskursen om kulturarv i Polen og Sverige, slik den kommer til syne i byer, på museer og på minnesteder.

Antologien består av tolv kapitler gruppert under tre hovedtemaer. Alle bidragene, så nær som ett, skriver seg fra forskningsprosjektet «Europeanization of realms of memory and the invention of a common European heritage».

Byer verden over deltar i et kappløp om å framstå som attraktive for investorer, for høyt utdannet arbeidskraft og for turister. Levende kulturliv, aktiv bruk av kulturminner og miljøvennlig byutvikling er sentrale bestanddeler i byenes posisjonering. Det første knippet kapitler i boka dreier seg om polske og svenske byers initiativer for å tiltrekke seg positiv oppmerksomhet som europeiske aktører. For å oppnå slik oppmerksomhet må byene vise at de er gode på inkludering. Forfatterne viser gjennom konkrete case hvordan forsøk på å inkludere «de andre» støter på problemer. «De andre» er alt fra jøder og tyskere til innvandrere, kvinner og narkomane. I de polske tilfellene er det i stor grad minnepolitikk som gjør inkludering vanskelig.

Sosiologen Paweł Kubicki peker på den sentrale rollen byene har i europeiseringsprosessen. I Øst- og Sentral-Europa, hevder Kubicki, har byene blitt oppfattet som en «metaforisk bro» som knytter den europeiske periferien til vesteuropeisk kultur. Derfor blir arbeidet med å utvikle byenes minne og kulturarv en del av europeiseringen. For Polen oppstår det da et problem, ettersom den polske nasjonen i liten grad har vært knyttet til byene. Bærerne av det polske, slik det har blitt framstilt tradisjonelt, er landadelen og bøndene. Kulturarv i polske byer vil måtte dreie seg mye om arven etter jødene og tyskerne som forsvant under og etter den andre 
verdenskrigen. Denne arven var tabu under folkerepublikken 1948-1989. Kombinert med modernismens "krig mot de andre", som Zygmunt Bauman formulerte det, ble de polske byene monoetniske, ikke bare befolkningsmessig, men også minnemessig. Kubicki peker på byfornyelsen av gamle, jødiske kvarterer som ett tiltak for å tilbakeføre noe av byenes "semiotiske polyglottisme» (Jurij Lotman), men kritiserer forsøkene for å ha endt opp som Disney-inspirerte temaparker. Da har han mer tro på de mange aktive bybevegelsene som finnes på grasrota i polske byer. Disse bevegelsene baserer seg på «retten til byen» (Henri Lefebvre) og inkluderer "de andre», slik Kubicki ser det.

Etnologen og historikeren Krzysztof Kowalski tar for seg byen Lublins forsøk på å få "det europeiske kulturarvmerket», som gis til bygninger, museer, dokumenter og annet som kan regnes som milepæler i utviklingen av Europa. Byen tok utgangspunkt i Lublinunionen (1569) Polen og Litauen gikk i realunion og opprettet det polsk-litauiske samveldet, Rzeczpospolitaen. Ideen var at dette skulle vise til en slags prototype for EU, og vise at det europeiske prosjektet kan strekkes ut over dagens EU.

Problemet er at Lublinunionen er kontroversiell i historieskrivingen til de folkeslagene som etter hvert utmeislet seg som hviterussere, ukrainere og baltiske litauere, og som har hjemstavn innenfor det som var Rzeczpospolitaen. Det som kunne høres ut som refleksiv kosmopolitisme vest i Europa, var for dem idyllisering av et undertrykkende «polskevelde».

Ved hjelp av begreper som "moralsk geografi» (noen hører hjemme et sted, andre ikke) og "retten til byen» analyserer Christine Hudson, Linda Sandberg og Ulrika Schumach Umeås forberedelser til en søknad om å bli europeisk kulturhovedstad 2014. I forberedelsene inngikk en plan for å inkludere «de andre» - de narkomane - i prosessen med å omforme knutepunktet Vasaplan.

Det andre knippet kapitler tar for seg museenes fortellinger om «annethet». Museene i Polen og Sverige har i ulik grad gått fra å være oppdragende institusjoner der de besøkende belæres ovenfra og ned om nasjonen som gitt størrelse, til å bli et sted der man blir utfordret og invitert til deltakelse rundt spørsmål om identitet.

Barbara Törnquist-Plewa sammenligner emigrasjonsmuseet i Gdynia med museet i Göteborg. Selv om begge museene baserer seg på forutsetningen at migrasjon er et naturlig fenomen, er det bare det svenske museet som aktivt engasjerer de besøkende i refleksjon rundt dagens immigrasjon. Törnquist-Plewa finner at museet i Gdynia ikke kobler sin framstilling av emigrasjonen til «offerrollen», som står sterkt i den for tiden dominerende nasjonalkonservative diskursen i Polen.

I et av bokas mest velskrevne kapitler tar etnologen Eleonora Narvselius for seg kulturarv som et betent tema i svensk politikk, der Miljöpartiet med kulturministeren og Sverigedemokraterna har gjort temaet til en merkesak.

Łukasz Bukowiecki skriver om hvordan den tyske kulturarven behandles i polske friluftsmuseer. Da Polens grense ble trukket langt inne i det som før hadde vært Tyskland, ble 3,2 millioner tyskere fordrevet. De nye, kommunistiske makthaverne 
iverksatte umiddelbart en "odniemczanie», avtysking av historieskrivingen. For eksempel ble tyske bygninger «negativ kulturarv». Gamle slaviske spor i området ble framhevet i tråd med begrepet «metodologisk nasjonalisme» - det at den staten som er, anses som naturlig og gitt. Innbyggerne i landsbyen Klucken ved Østersjøen ble ikke fordrevet, men ble omdefinert som slavere og skulle utgjøre folkeslaget "slovintsere». Friluftsmuseet i landsbyen underbygger denne fortellingen.

I kapitlet om galiziajødenes museum i Kraków gir statsviteren Katarzyna Suszkiewicz museet svært positiv omtale, men kapitlet kunne med fordel ha diskutert faren for den disneyfiseringen Kubicki advarer mot i sitt kapittel.

Sosiologen Łucja Piekarska-Duraj drøfter måten kvinner blir representert på i museene. Hun benytter seg av Ferdinand de Saussures distinksjon mellom "langue» og "parole» og argumenterer for at "parole» bedre dekker den erfarte historien (kvinner), mens "langue» dekker strukturene (menn).

Det tredje knippet kapitler dreier seg om representasjon av «de andre» i krigenes kulturarv. Her viser Niklas Bernsand hvordan første verdenskrig har blitt et minnepolitisk tema i Sverige som følge av en felles europeisk minnepolitikk. Casen hans er behandlingen av de ilanddrevne likene etter Skagerrakslaget i 1916. Statsviteren Elisabeth Wassermann tar for seg den polske hjemmehærens museum i Kraków og finner sterke innslag av at det spilles på offerrollen. De 150000 polakkene som ble massakrert av de ukrainske nasjonalistene i UPA mellom 1943 og 1945, omtales behørig i museet, men intet er nevnt om Hjemmehærens framferd overfor lokale ukrainere. Sosiologen og antropologen Zdzisław Mach drøfter hvordan kulturarven etter folkeslag som tidligere bebodde et område (tyskerne og jødene i Polen), skal behandles.

Gitt temaet for boka og det polsk-svenske forfatterlaget er det overraskende at ikke flere av kapitlene er eksplisitt komparative. De offisielle versjonene av Polen og Sverige er jo for tiden ytterpunkter i Europa hva åpenhet for annethet angår. Det er også overraskende at minnepolitikk ikke belyses mer direkte i flere av bidragene. Narvselius' bidrag er et hederlig unntak her, men det omfatter bare Sverige. Sett på bakgrunn av den sentrale rollen minnepolitikk basert på «metodologisk nasjonalisme» har i det polske regjeringspartiets profil og bevilgningspolitikk, er dette et savn.

Det er stor variasjon mellom kapitlene med hensyn til hvor klar argumentasjonen er, og hvor godt påstander underbygges teoretisk og empirisk. Et par av kapitlene kunne med fordel ha blitt strammet opp, språkvasket grundigere og korrekturlest nøyere.

Med sine mange ulike case, detaljer og vinklinger og referanser til et bredt utvalg debatter og litteraturer vil boka likevel være en gullgruve for studenter som planlegger en masteroppgave eller doktorgrad om kulturarv, museologi og minnepolitikk i lys av begrepet «annethet». Boka er til inspirasjon og anbefales. 